\title{
The Effect of Financial Restructuring on the Overall Financial Performance of the Commercial Banks in Vietnam
}

\author{
Tam Thanh Nguyen DUONG ${ }^{1}$, Hai Thanh PHAN ${ }^{2}$, Tien Ngoc HOANG ${ }^{3}$, Tien Thuy Thi VO
}

Received: July 03, 2020 Revised: July 25, 2020 Accepted: August 10, 2020

\begin{abstract}
The study investigates and measures the impact of financial restructuring on overall financial performance of commercial banks in Vietnam. Survey data for this research were collected from audited financial reports of 28 commercial banks in Vietnam, for the period from 2008 to 2018. In the study, we have built a model of econometric regression with the dependent variable being financial results measured through ROA and ROE. The research methods used include Pooled Ordinary Least Square Model (POLS), Fixed Effects Model (FEM), Random Effects Model (REM), and different Generalized Method of Moments (GMM). The results showed that the account payables restructuring and owners' equity restructuring are much needed. Increasing the owners' equity, decreasing the account payables would improve the overall financial performance, bad debts restructuring to decrease bad debts would also improve the financial performance as well. However, the financial restructuring in the period 2012-2015 and 2016-2018, indeed worsen the financial performance during those times. The findings of this study suggest that the evaluation of the financial performance after restructuring of commercial banks in Vietnam must be based on longer data. At the same time, it is necessary to examine differences between various banking groups to draw accurate conclusions on financial performance.
\end{abstract}

Keywords: Financial Restructuring, Financial Performance, Commercial Banks, Quantitative Research Method, Vietnam

JEL Classification Code: L25, P47, G34, G32

\section{Introduction}

Globalization in the financial markets has created a very competitive environment for the international commercial banks. In such an environment, the overall financial performance of commercial banks has become very important (Harker \& Zenios, 2000; Isik \& Hassan, 2002). The commercial banks have to work more effectively and

${ }^{1}$ First Author. PhD Student, Lecturer, Banking University of Ho Chi Minh City, Ho Chi Minh City, Vietnam. Email: tamdnt@buh.edu.vn ${ }^{2}$ Corresponding Author. Associate Professor, Faculty of Accounting, Institute of Research and Development, Duy Tan University, Da Nang, Vietnam [Postal Address: 254 Nguyen Van Linh Street, Thanh Khe District, Da Nang City, 550000, Vietnam] Email: phanthanhhai@ duytan.edu.vn

${ }^{3}$ Lecturer, Graduate School, Duy Tan University, Da Nang, Vietnam. Email: tienvjc@gmail.com

${ }^{4}$ Lecturer, VNUK Institute for Research and Executive, The University of Da Nang, Da Nang, Vietnam. Email: tien.vo@vnuk.edu.vn

(c) Copyright: The Author(s)

This is an Open Access article distributed under the terms of the Creative Commons Attribution Non-Commercial License (https://creativecommons.org/licenses/by-nc/4.0/) which permits unrestricted non-commercial use, distribution, and reproduction in any medium, provided the original work is properly cited. more efficiently to decrease their costs. They have to grow and apply new technologies, provide new products and services to be able to compete in this environment. In fact, in this competitive market, the banking systems of many developing economies are still very weak and ineffective. To resolve this problem, the financial restructuring had been done to improve the financial performance of banks (Denizer et al., 2007; Isik \& Hassan, 2002; Zhao et al., 2010). These restructuring activities will help banks to improve their financial performance, better allocate the resources, initiate innovations, increase profits, improve service quality for customers and maintain the stability in the financial system (Osoro, 2014). In many cases, financial restructuring is no longer an option, it is indeed one of the critical actions for the survival and growth of a bank (Rogovsky et al., 2005).

Vietnam has been a fast-growing country in the South East Asia region in the past centuries. However, with the hit of the world crisis in 2007, the commercial accounting system in Vietnam faced many difficulties, especially shortcomings in finance, high rate of bad debts, risks in liquidity issues, and legal matters. New commercial banks were established, but many were under pressure to survive and grow. Therefore, 
financial restructuring to increase the overall financial performance, and to ensure the survival and development of banks is necessary. In the past, there are many studies on the financial restructuring and performance of commercial banks in Vietnam, such as research by Tran et al. (2014), Dao and Nguyen (2020), Tran (2020). However, there is no single research that looks at the financial restructuring of commercial banks in Vietnam for the period after 2008. This is a very important time after the world financial crisis. Therefore, our research is timely.

This research is done with the following objectives: (i) the overall study of the financial restructuring on financial performance of commercial banks in Vietnam, and their relationship to other important economic factors; (ii) presents the research model and the hypotheses, including research design, analysis, and discussion of the results for the period of 2008-2018; (iii) concludes the research and indicates areas to improve, and suggest further research.

\section{Literature Review}

\subsection{Restructuring and Financial Performance}

According to Dziobek and Pazarbasioglu (1997), banking restructuring is a solution to improve the overall performance for commercial banks, including paying capacity and profiting capacity, improving the efficiency ability, and gaining the public trust. Also, there are four types of banking restructuring: financial restructuring, operational restructuring, assets restructuring, and capital restructuring. However, Osoro (2014) said that the restructuring focuses on financial restructuring and often related to the payable and capital structures.

The organization's effectiveness and success are also the ability in using different resources effectively and the ability to achieve the organization's objectives (Worthington, 2009). According to Gardner et al. (2004), Thompson and Garbacz (2007), the success of the organization can be measured financially or non-financially. The measurement methods for the financial performance could be the accounting measurement methods, non-accounting measurement methods, or market-based measurement methods in which the measurement method based on accounting data is the method that uses mainly the balance sheet and financial accounting reports. (Rose, 1994). The measurement method using financial information include return-on-assets (ROA), return on equity (ROE), and return on sales (ROS) (Shih-Jen \& Mckay, 2002; Hu \& Izumida, 2008; Le \& Buck, 2011; Majeed et al., 2020 ). Rose (1994) said that the most popular measurement methods using financial data are ROA, ROE, and net interest margin (NIM). The ROA and ROE are the ratios showing the performance of the current business and express the profits that banks had accumulated during the past accounting periods.

\subsection{The Influence of Financial Restructuring on the Financial Performance}

Dziobek and Pazarbasioglu (1997) argued that the commercial banks restructured to improve the financial performance or increase the size of financial services provided to the customers, increasing their competitiveness. Through the studies of 24 countries participating in the restructuring in the 1980s and 1990s, the overall financial performance of commercial banks was considered by two factors: the liquidity ratio and the profit ratio. The ratios used to evaluate the liquidity include bad debt ratio, and the capital-to-asset ratio. The profit ratios include the operating expense-to-asset ratio, income-to-asset ratio, and the profitto-asset ratio. The research method used includes summary, report, analysis and comparison to determine the ratios.

Rose (1994) studied the financial restructuring and operational restructuring of almost 730 commercial banks in the U.S. in the crisis period 1980-1990. The research examined the influence of restructuring on the overall financial performance of the commercial banks. The financial performance tools used in the research were ROA, ROE, and NIM. The measurement ratio for operational restructuring is the income/expenses ratio and operational expenses/ total assets ratio. Financial restructuring is determined by long-term debt over total assets. In the meantime, assets restructuring is measured by using bad debts divided by total credit outstanding and loan value divided by total credit outstanding. The research methods used are describing analysis methods and OLS methods. The results showed that the restructured banks had higher profits and consistently improved during the last half of the century.

Osoro (2014) has researched the influence of financial restructuring on the overall financial performance of the commercial banks in Kenya. This research studied 11 commercial banks traded on the Nairobi Security Exchange (NSE) and their activities in the period 2008-2013. Debt ratio, dividend paying ratio, and capital ratio were used as means of financial restructuring solutions. Financial performances were measured by ROE. The research used multiple variables linear regression to analyze the data. The research showed that financial restructuring had a positive effect on the financial performance of the commercial banks in Kenya.

Akhtar et al. (2011) studied the factors affecting the financial performance of commercial banks in Pakistan in 2006-2009; results showed that debt-to-equity ratio and safety margin ratio had positive effect on financial performance measured by ROA, ROE of the commercial banks. This research also pointed out that the banks' size had little effect on the financial performance. Kithinji (2017) said that banks with different characteristics have a positive effect on the relationship between restructuring (financial restructuring, 
operational restructuring, assets restructuring, and capital restructuring) and the overall financial performance of 39 commercial banks in Kenya for the period 2002-2014.

Beside research on the effect of restructuring and bank's characteristics on the financial performance, other authors also study the macro factors. Kolapo et al. (2012) studied the effect of the credit risk on the financial performance of commercial banks in Nigeria for the period 2000-2011. In the research, the authors used the variable ROA to measure the financial performance, credit risk is measured by the bad debt ratio, loans-to-deposit ratio, and the allowance for doubtful account ratio. The research determined that bad debt ratio and the allowance for doubtful account had negative effect on the performance, whereas the increase in loan credit had positive effect on the financial performance.

Hsiao et al. (2010) studied the influence of financial restructuring on the financial performance in Taiwan. The authors used the Data Envelopment Analysis (DEA) for 40 commercial banks in the period 2000-2005. Study showed that even though banks performed not quite well in the period before restructuring (2002-2003), they all improved in the period post-restructuring (2004-2005). The results were not changed after the authors re-check with the bad debt ratio, safety margin ratio, size, and growth rate of the GDP. The results also showed that the performance improved thanks to increasing bank management activities, risk management activities, and others benefits from financial restructuring.

Thoraneenitiyan and Avkiran (2009) measured the influence of restructuring factors and country's unique factors on the performance of the commercial banks in South Asia after the financial crisis. It combined the DEA model and SFA model for the period of 1997-2001; five countries that were heavily influenced by the bank crisis in 1997 did engage in the banking system restructuring (Indonesia, South Korea, Thailand, Malaysia, and the Philippines), including 110 banks and 550 observations. The authors measured the restructuring related to bank owners' equity, mergers, participation of foreign banks, and the government's involvement. This research provided an important real-life analysis about the influence of restructuring variable factors after the crisis and the country's unique factors on the performance of commercial banks in Asia's developing countries. The study showed that banks merger in each country had created better performing banks, but overall, the restructuring did not make the banking system perform better.

Tran et al. (2014) evaluated the influence of restructuring on commercial banks' performance in Vietnam. Three restructuring methods mentioned in the research were: merger, government's intervention, and privatization. The research showed that because the commercial banks were in the process of restructuring, therefore their performance varied without delineating trends or predictions. The banks that did merger had decreased performance because they had to bear the under-performance of smaller and weaker banks. The governmental banks performed badly when the government intervened. The government banks that were privatized performed better after being privatized.

\section{Data and Research Methodology}

\subsection{Data}

The research data were collected from the commercial banks trading on HOSE and HNX for the period 2008-2018. The data used in this research is the Unbalanced Panel Data. The data was collected from 2008, because Vietnam has joined WTO since 2007, and the world financial crisis started in 2008, the commercial banks in Vietnam had performed many operational restructuring since then. The secondary data was collected from the audited financial reports of the commercial banks.

\subsection{Research Methods}

\subsubsection{Research Model}

The research model measures the relationship between restructuring and financial performance of commercial banks in Vietnam was developed by many authors (Table 1). The model is illustrated as follow:

$$
\begin{aligned}
\mathrm{FP}_{\mathrm{t}}= & \mathrm{f}\left(\alpha, \mathrm{FP}_{\mathrm{t}-1}, \operatorname{LITE}_{\mathrm{it}}, \mathrm{ETA}_{\mathrm{it}}, \mathrm{NPL}_{\mathrm{it}}, \operatorname{SIZE}_{\mathrm{it}} \operatorname{GDP}_{\mathrm{it}}, \mathrm{INF}_{\mathrm{it}},\right. \\
& \left.\mathrm{RE} 1_{\mathrm{it}}, \mathrm{RE}_{\mathrm{it}}, \mathrm{u}\right)
\end{aligned}
$$

In this model, dependent variables are financial results $\left(\mathrm{ROA}_{\mathrm{t}}, \mathrm{ROE}_{\mathrm{t}}\right)$ and are labeled $\mathrm{FP}_{\mathrm{t}}$

- The independent variables are: (1) financial results of commercial banks interrelated through the time $\left(\left(\mathrm{FP}_{\mathrm{t}-1}\right) ;(2)\right.$ Debt ratio (LITE $\left.{ }_{\mathrm{it}}\right)$; (3) Owners' capital/ total assets ratio $\left(\mathrm{ETA}_{\mathrm{it}}\right)$; (4) Bad debt ratio $\left(\mathrm{NPL}_{\mathrm{it}}\right)$;

- Control variable is commercial banks' size ( SIZE $\left._{\mathrm{it}}\right)$;

- Macro variables include: economic growth $\left(\mathrm{GDP}_{\mathrm{it}}\right)$ and inflation rate $\left(\mathrm{INF}_{\mathrm{it}}\right)$;

- Dummy variables include: (1) RE1 $1_{\mathrm{it}}$ : restructuring in period 1 from 2012-2015, 0: before restructuring period 2008-2011, restructuring in period 2 from 2016-2018); (2) $\mathrm{RE}_{\text {it }}$ (1: restructuring in period 2 from 2016-2018, 0: before restructuring period 2008-2011, restructuring in period 1 from 20122015).

- $\quad$ Other factors: $\alpha$ (the intercept), i (banks), t (year).

\subsubsection{Research Methods}

This research used multiple variable linear regression to analyze the influence of financial restructuring factors on 
the overall financial performance of commercial banks in Vietnam for the period 2008-2018 using Stata software. We used data from 28 commercial banks in Vietnam and formed an Unbalanced Panel Data (due to some empty data). We used the POLS regression model to test the influence of the financial restructuring on the overall financial performance. However, the POLS regression model required permanent time and factors, therefore the data used in this table is not satisfied. To resolve this problem of the POLS model, we used the FEM regression model.

To choose between POLS or FEM, we used Fisher's exact test with the hypothesis: H0: $\alpha_{i}=0$ with all $\alpha_{i}$. (choose model POLS), H1: exist $\alpha_{i} \neq 0(j=1, n)$ (choose model FEM). The results were shown from $p$-value from the test. If $p \geq \alpha$, accept $\mathrm{H} 0$, choose POLS model, if $\mathrm{p}<\alpha$, reject $\mathrm{H} 0$, choose model FEM.

Choosing model REM considers the differences of factors through time, therefore the results do not show heteroskedasticity. Hausman testing was, then, performed to determine the independence of $\alpha_{i}$ and choose between the permanent affecting model or the random affecting model. The hypothesis is formulated as follows: H0: the independent variables have no errors (choose model REM), H1: $\operatorname{Cov}(\mathrm{Xjit}$, $\left.\alpha_{\mathrm{i}}\right) \neq 0$ (choose model FEM). If $\mathrm{p}$-value $<0.05$, ignore H0. If that is the case, REM is not suitable, we should use FEM.
However, the consideration model used within regression has varied data, therefore we suggest using the model DPD with difference equation: the Difference GMM suggested by Arellano and Bond (1995) to increase the expected results.

\section{Results}

\subsection{Descriptive Analysis}

Based on Table 2, we can see that the dependent variable ROA (profit ratio over the total assets) has the mean of 0.0092 , the variance is quite large 0.0086 , the maximum value is 0.0595 and the minimum value is -0.0599 . The dependent variable ROE (profit ratio over total capital) has mean value of 0.0964 , variance is 0.0808 , minimum value is -0.0563 and maximum value is 0.3153 .

The independent variable LITE (payables over total capital ratio) has the mean value of 11 showing that banks use debt payable 11 times more than the owners' capital amount, the variance of 5.17 times is quite significant. Within the variable, the highest debt payable to owners' capital is 29 times. The owners' capital to the mobilized capital ratio has the lowest value of 0.1034 , standard variance of 0.0595 , lowest ratio is 0.0325 , and the highest ratio is 0.4624 . The bad debt ratio average is 0.0227 , standard variance is 0.0155 ,

Table 1: Variables. Description relationship, and Methods

\begin{tabular}{|c|c|c|c|c|c|}
\hline Variables & Description relationship & Sources & Method & Result & Expect \\
\hline Financial results & \begin{tabular}{|l|}
$\operatorname{lag}(\mathrm{ROA})$ \\
$\operatorname{lag}(\mathrm{ROE}$
\end{tabular} & Lee \& Kim (2013) & OLS & + & + \\
\hline Debt ratio & $\begin{array}{l}\text { Total Payables/Owners' } \\
\text { capital }\end{array}$ & Akhatar et al (2011); Osoro (2014) & OLS & - & - \\
\hline Capital ratio & Owners' capital/Total assets & $\begin{array}{c}\text { Dziobek \& Pazarbasioglu (1997); } \\
\text { Osoro (2014) }\end{array}$ & OLS & + & + \\
\hline Bad debt ratio & Bad debts / Total receivables & $\begin{array}{c}\text { Rose (1994), Dziobek \& } \\
\text { Pazarbasioglu (1997); Kolapo et } \\
\text { al (2012); Hsiao et al (2010) }\end{array}$ & $\begin{array}{l}\text { OLS } \\
\text { GMM } \\
\text { DEA }\end{array}$ & - & - \\
\hline Size & Ln(Total Assets) & $\begin{array}{l}\text { Hsiao et al (2010); Barko et al } \\
\text { (2013); Kithinj (2017) }\end{array}$ & $\begin{array}{l}\text { DEA } \\
\text { GMM } \\
\text { OLS }\end{array}$ & + & + \\
\hline $\begin{array}{l}\text { Economic growth } \\
\text { rate }\end{array}$ & $\operatorname{Ln}\left[\left(G P_{t}-G D P_{t-1}\right) / G D P_{t-1}\right]$ & $\begin{array}{l}\text { Hsiao et al (2010); Akhtar et al } \\
\text { (2011) }\end{array}$ & $\begin{array}{l}\text { DEA } \\
\text { GMM }\end{array}$ & + & + \\
\hline Inflation rate & $\operatorname{Ln}\left[\left(\mathrm{INF}_{\mathrm{t}}-\mathrm{INF}_{\mathrm{t}-1}\right) / \mathrm{INF} \mathrm{F}_{\mathrm{t}-1}\right]$ & Akhtar et al, (2011) & GMM & - & - \\
\hline $\begin{array}{l}\text { Restructuring } \\
\text { period } 1\end{array}$ & $\begin{array}{l}\text { Restructuring period 1: } 1 \text {, } \\
\text { Before restructuring: 0, } \\
\text { Restructuring period 2: } 0 \\
\end{array}$ & Hsiao et al (2010) & DEA & - & - \\
\hline $\begin{array}{l}\text { Restructuring } \\
\text { period } 2\end{array}$ & $\begin{array}{l}\text { Restructuring period } 2: 1 \text {, } \\
\text { before restructuring : } 0 \text {, } \\
\text { Restructuring period } 1: 0\end{array}$ & Hsiao et al (2010) & DEA & - & - \\
\hline
\end{tabular}


the highest ratio is 0.1261 . The banks' size variable measured by $\mathrm{Ln}$ (total assets) has the average value of 18,1950 compared to the standard variance, lowest value is 14,6978 , and the highest value is 20,9956 . The macro factor GDP has the average value of 0.0611 , standard variance of 0.0059 . The macro factor INF has the average value of 0.0806 , the variance is pretty high at 0.0659 , the lowest inflation rate in 2016: 0.0324 and the highest inflation rate in 2008: 0.2312 .

\subsection{Correlation Analysis}

The correlation factors between the variables are low, however, there are still some high correlation between the variable pairs such as ETA-LITE, ETA-SIZE (see Table 3). The variables in the model have high correlation and have led to the model becoming multi-collinear, and the results of independent factors affecting the dependent factors were not accurate. Next, we examined the multi-collinear of the model using the variance inflation VIF, this VIF factor for ROA has the average value not too high of 3.05 , varied from 1.1 to 5.52 , for ROE is 3.14 and varied from 1.09 to 5.74 . These VIF confirmed that the model is not multicollinearity.

We used graphs to analyze the change in financial performance of commercial banks in Vietnam in the period of 2008-2018 and compare the change in performance of commercial banks in different periods: before restructuring, restructuring period 1 (2012-2015) and restructuring period 2 (2016-2018). Before the restructuring period in 2012, average ROA was above $1 \%$, the highest rate of $1.6 \%$ was in 2009 (for each 100 dollars invested value can get a return of 1.6 dollars profit after tax). In the first restructuring period (2012-2015), average ROA decrease sharply to $0.5 \%$, showing that the financial performance of the commercial banks in Vietnam in this period decreased, moving forward to the $2^{\text {nd }}$ period, the ROA improved, however not much $(0.9 \%$ in 2018$)$ and did not recover as the stage before the restructuring period.

Table 2: Descriptive analysis for the variables used in the model

\begin{tabular}{|l|c|c|c|c|c|}
\hline Variable & $\mathbf{N}$ & Mean & Std & Min & Max \\
\hline ROA & 307 & 0.0092 & 0.0086 & -0.0599 & 0.0595 \\
\hline ROE & 307 & 0.0964 & 0.0808 & -0.5633 & 0.3153 \\
\hline LITE & 307 & 11.0766 & 5.1453 & 1.1624 & 29.7014 \\
\hline ETA & 307 & 0.1034 & 0.0596 & 0.0326 & 0.4624 \\
\hline NPL & 307 & 0.0227 & 0.0155 & 0 & 0.1261 \\
\hline SIZE & 307 & 18.1950 & 1.3058 & 14.6987 & 20.9956 \\
\hline GDPt & 308 & 0.0611 & 0.0059 & 0.0525 & 0.0708 \\
\hline INFt & 308 & 0.0878 & 0.0618 & 0.0324 & 0.2312 \\
\hline RE1 & 308 & 0.4545 & 0.4987 & 0 & 1 \\
\hline RE2 & 308 & 0.2727 & 0.4461 & 0 & 1 \\
\hline
\end{tabular}

Table 3: Independent variable correlation matrix

\begin{tabular}{|l|c|c|c|c|c|c|c|c|c|}
\hline & ROA & ROE & LITE & ETA & NPL & SIZE & GDPt & INFt & RE1 \\
\hline ROA & 1 & & & & & & & & \\
\hline ROE & 0.7570 & 1 & & & & & & & \\
\hline LITE & -0.3073 & 0.1689 & 1 & & & & & & \\
\hline ETA & 0.3675 & -0.1765 & -0.8135 & 1 & & & & & \\
\hline NPL & -0.1178 & -0.1018 & -0.0615 & -0.0014 & 1 & & & & \\
\hline SIZE & -0.1321 & 0.3146 & 0.7581 & -0.7233 & 0.0299 & 1 & & & \\
\hline GDPt & -0.1168 & -0.0665 & 0.1084 & -0.2579 & 0.0303 & 0.1931 & 1 & & \\
\hline INFt & 0.0615 & -0.0653 & -0.2917 & 0.2144 & 0.0211 & -0.2592 & 0.0268 & 1 & \\
\hline RE1 & -0.2068 & -0.2276 & -0.1304 & -0.0170 & 0.2026 & 0.0496 & 0.3826 & 0.5059 & 1 \\
\hline RE2 & -0.1500 & -0.0054 & 0.3457 & -0.2723 & -0.103 & 0.3123 & 0.0072 & -0.8712 & -0.5619 \\
\hline
\end{tabular}




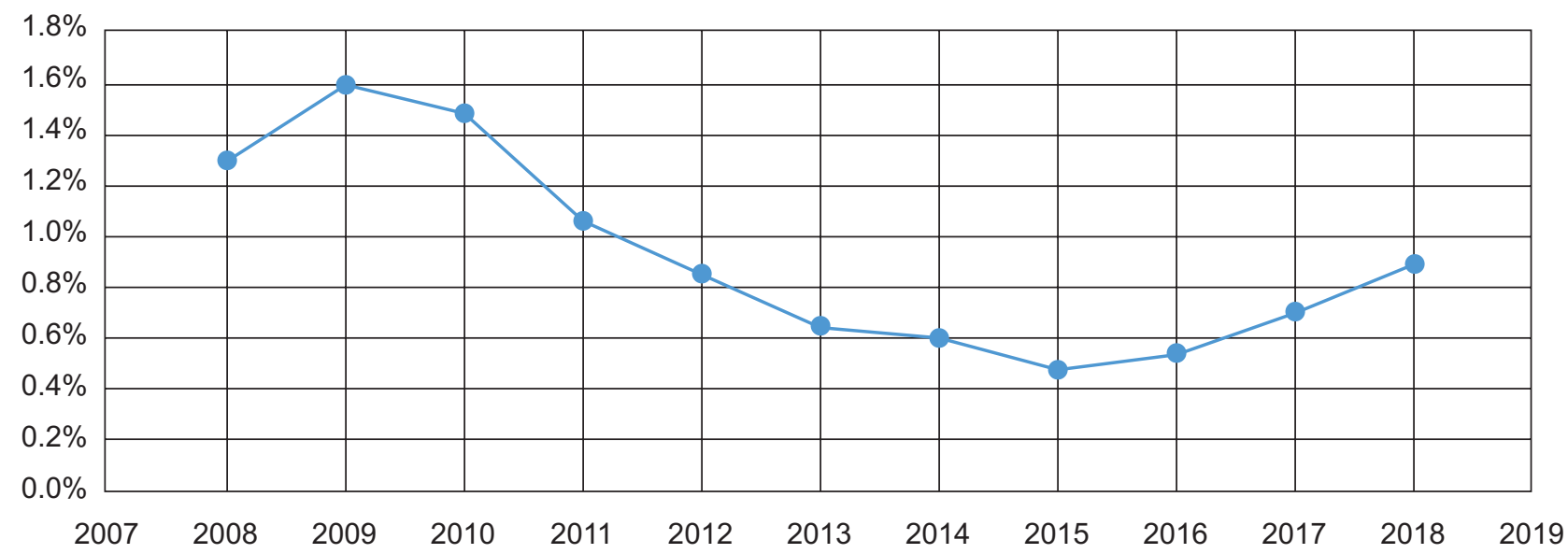

Figure 1: Average ROA of the commercial banks in Vietnam, period 2008 - 2018

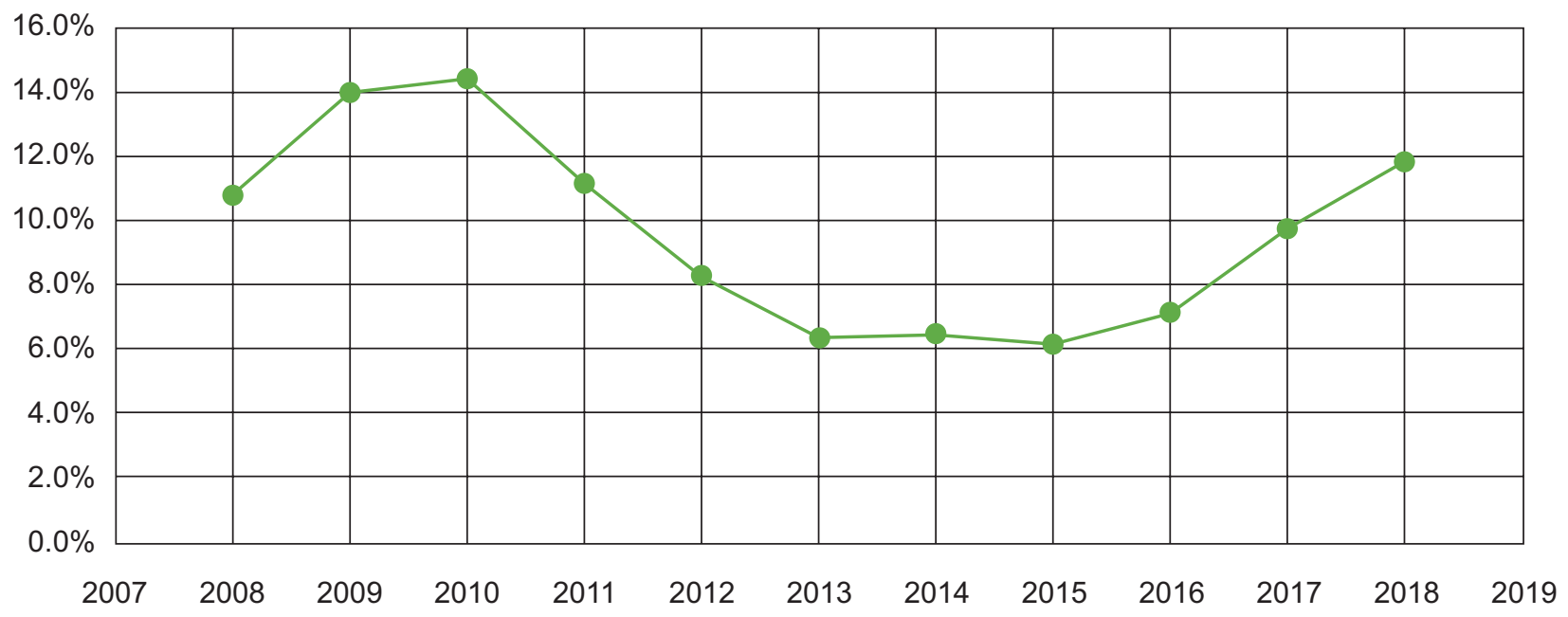

Figure 2: Average ROE of Vietnam commercial banks in period 2008 - 2018

The return-on-equity $\mathrm{ROE}$ ratios of the commercial banks in Vietnam for the period before restructuring from 2008 to 2010 were from $10.8 \%$ to $14.3 \%$, showing that for every 100 dollars of capital invested, there is a return of 14.3 dollars after tax. However in 2011, the ROE ratio decreased to $11.1 \%$, showing that the banks' performance worsen compared to the period 2012-2015, ROE ratio of Vietnam commercial banks continued to decrease to $6.1 \%$ in 2015 and, when entering the $2^{\text {nd }}$ restructuring period, this ratio has improved to $11.8 \%$ in 2018 .

To evaluate the influence of the financial restructuring on the overall financial performance of Vietnam's commercial banks, this research used eight regression models, in which four models - POLS, FEM, REM, DGMM - are used to evaluate the influence of financial restructuring factors on the ROA, and four other models are used to evaluate the influence of financial restructuring factors on the ROE. The results showed that all eight models are statistically meaningful.

Based on Table 4, model POLS 1 showed that the influence of financial restructuring factor on ROA explained $48.6 \%$. The model showed that the mentioned variables are more meaningful compared to the result of $26.7 \%$ from model Osoro (2014). The results also showed that other variables affecting ROA with $1 \%$ meaning such as ROA, ETA, SIZE, RE1, RE2, 5\% meaning such as INF, 10\% meaning such as LITE, the variables NPL and GDP have no statistical meaning. Model POLS 2 showed that the influence of financial restructuring on the ROE explained $47.3 \%$. 
Table 4: Research results on the influence of financial restructuring on the overall financial performance of Vietnam's commercial banks.

\begin{tabular}{|c|c|c|c|c|c|c|c|c|}
\hline Model & POLS1 & FEM1 & REM1 & DGMM1 & POLS2 & FEM2 & REM2 & DGMM2 \\
\hline Variables & ROA & ROA & ROA & ROA & ROE & ROE & ROE & ROE \\
\hline \multirow[t]{2}{*}{ L.ROA } & $0.361^{* * *}$ & $0.253^{* * *}$ & $0.361^{* * *}$ & $0.311^{* * *}$ & & & & \\
\hline & {$[7.71]$} & {$[4.98]$} & {$[7.71]$} & {$[17.90]$} & & & & \\
\hline \multirow[t]{2}{*}{ L.ROE } & & & & & $0.477^{* * *}$ & $0.301^{* * *}$ & $0.477^{* * *}$ & $0.347^{* * *}$ \\
\hline & & & & & {$[9.01]$} & {$[5.07]$} & [9.01] & {$[9.95]$} \\
\hline \multirow[t]{2}{*}{ LITE } & $-0.000402^{*}$ & $-0.000331^{* *}$ & $-0.000402^{* *}$ & $-0.000448^{* * *}$ & $-0.00281^{*}$ & $-0.00072^{*}$ & $-0.00281^{*}$ & $-0.00181^{* *}$ \\
\hline & {$[-2.55]$} & {$[-1.64]$} & {$[-2.55]$} & {$[-5.38]$} & {$[-1.78]$} & {$[-0.36]$} & {$[-1.78]$} & {$[-1.52]$} \\
\hline \multirow[t]{2}{*}{ ETA } & $0.0532^{* * *}$ & $0.0881^{* * *}$ & $0.0532^{* * *}$ & $0.130^{* * *}$ & $0.0792^{*}$ & $0.354^{*}$ & $0.0792^{*}$ & $0.767^{* * *}$ \\
\hline & [3.33] & [4.63] & [3.33] & [13.39] & {$[0.50]$} & [1.88] & {$[0.50]$} & {$[3.45]$} \\
\hline \multirow[t]{2}{*}{$\mathrm{NPL}$} & -0.0265 & $-0.00852^{*}$ & -0.0265 & $-0.0189^{*}$ & -0.262 & $0.109^{*}$ & $-0.262^{*}$ & $-0.0397^{* *}$ \\
\hline & {$[-1.09]$} & {$[-0.30]$} & {$[-1.09]$} & {$[-1.11]$} & {$[-1.10]$} & {$[0.38]$} & {$[-1.10]$} & {$[-0.35]$} \\
\hline \multirow[t]{2}{*}{ SIZE } & $0.00265^{* * *}$ & $0.00781^{* * *}$ & $0.00265^{\star * *}$ & $0.00493^{* * *}$ & $0.0236^{* * *}$ & $0.0645^{\star \star *}$ & $0.0236^{* * *}$ & $0.0516^{* * *}$ \\
\hline & [5.49] & {$[4.80]$} & [5.49] & [4.83] & {$[4.62]$} & [3.92] & [4.62] & [3.06] \\
\hline \multirow[t]{2}{*}{ GDP } & 0.00188 & $0.00373^{*}$ & 0.00188 & $0.00289^{* * *}$ & $0.0154^{*}$ & $0.0283^{* *}$ & $0.0154^{*}$ & $0.0206^{* * *}$ \\
\hline & [1.38] & {$[2.58]$} & {$[1.38]$} & {$[5.94]$} & {$[1.14]$} & [1.97] & {$[1.14]$} & {$[2.87]$} \\
\hline \multirow[t]{2}{*}{ INF } & $-0.00177^{* *}$ & $-0.00219^{* * *}$ & $-0.00177^{* *}$ & $-0.00165^{\star * *}$ & $-0.0160^{* *}$ & $-0.0203^{* * *}$ & $-0.0160^{* *}$ & $-0.0177^{* * \star}$ \\
\hline & {$[-2.36]$} & {$[-2.94]$} & {$[-2.36]$} & {$[-8.87]$} & {$[-2.13]$} & {$[-2.73]$} & {$[-2.13]$} & {$[-7.25]$} \\
\hline \multirow[t]{2}{*}{ RE1 } & $-0.00712^{* \star *}$ & $-0.0108^{* * *}$ & $-0.00712^{* * *}$ & $-0.00750^{* * *}$ & $-0.0635^{\star * *}$ & $-0.0955^{\star * *}$ & $-0.0635^{* * *}$ & $-0.0772^{\star \star *}$ \\
\hline & {$[-6.77]$} & {$[-7.33]$} & {$[-6.77]$} & {$[-8.73]$} & {$[-6.04]$} & {$[-6.45]$} & {$[-6.04]$} & {$[-4.96]$} \\
\hline \multirow[t]{2}{*}{ RE2 } & $-0.00788^{\star * *}$ & $-0.0146^{* \star *}$ & $-0.00788^{* * *}$ & $-0.00798^{* * *}$ & $-0.0670^{\star \star *}$ & $-0.129^{\star * \star}$ & $-0.0670^{* * *}$ & $-0.0906^{\star \star *}$ \\
\hline & {$[-4.27]$} & {$[-5.65]$} & {$[-4.27]$} & {$[-7.95]$} & {$[-3.57]$} & {$[-4.90]$} & {$[-3.57]$} & {$[-4.91]$} \\
\hline \multirow[t]{2}{*}{ _cons } & $-0.0362^{* * *}$ & $-0.129^{* * *}$ & $-0.0362^{* * *}$ & $-0.0832^{* * *}$ & $-0.293^{* * *}$ & $-1.039^{* * *}$ & $-0.293^{* * *}$ & $-0.859^{* * *}$ \\
\hline & {$[-4.10]$} & {$[-4.55]$} & {$[-4.10]$} & {$[-4.58]$} & {$[-3.24]$} & {$[-3.65]$} & {$[-3.24]$} & {$[-2.78]$} \\
\hline$N$ & 279 & 279 & 279 & 251 & 279 & 279 & 279 & 251 \\
\hline R-sq & 0.486 & 0.447 & & & 0.473 & 0.329 & & \\
\hline Mean VIF & \multicolumn{4}{|c|}{3.05} & \multicolumn{4}{|c|}{3.14} \\
\hline White test & \multicolumn{4}{|c|}{$\begin{array}{c}\text { White's test for Ho: homoskedasticity } \\
\text { against Ha: unrestricted heteroskedasticity } \\
\text { chi2 }(49)=97.39 \\
\text { Prob }>\text { chi2 }=0.0000\end{array}$} & \multicolumn{4}{|c|}{$\begin{array}{c}\text { White's test for Ho: homoskedasticity } \\
\text { against Ha: unrestricted heteroskedasticity } \\
\text { chi2 }(49)=105.81 \\
\text { Prob }>\text { chi2 }=0.0000\end{array}$} \\
\hline \multirow{2}{*}{ Fisher test } & \multirow{2}{*}{\multicolumn{4}{|c|}{$\begin{array}{c}\mathrm{F} \text { test that all } \mathrm{u}_{\mathrm{B}} \mathrm{i}=0: \\
\mathrm{F}(27,242)=1.58 \quad \text { Prob }>F=0.0396\end{array}$}} & \multicolumn{4}{|c|}{$\mathrm{F}$ test that all $\mathrm{u}_{-} \mathrm{i}=0$ : } \\
\hline & & & & & \multirow{2}{*}{\multicolumn{4}{|c|}{$\mathrm{HO}$ : overidentifying restrictions are valid }} \\
\hline Sargan test & \multicolumn{4}{|c|}{ HO: overidentifying restrictions are valid } & & & & \\
\hline $\begin{array}{l}\text { Arellano } \\
\text { Bond test }\end{array}$ & \multicolumn{4}{|c|}{$\begin{array}{l}\text { H0: no autocorrelation } \\
\text { Prob }>z=0.8632\end{array}$} & \multicolumn{4}{|c|}{$\begin{array}{c}\text { H0: no autocorrelation } \\
\text { Prob }>z=0.9104\end{array}$} \\
\hline
\end{tabular}

t statistics in brackets ${ }^{*} p<0.1,{ }^{* *} p<0.05,{ }^{* * *} p<0.01$

The other factors were not mentioned in the model. The results showed that variable factors affecting ROE with $1 \%$ meaning such as ROE, SIZE, RE1, RE2; with 5\% meaning such as INF; with 1\% meaning such as LITE, ETA, GDP; the NPL variable has no statistical meaning. Through the White testing, the result showed that p-value of the POLS1 and POLS2 models were both $0.0000<5 \%$, therefore there is heteroscedasticity. 
With the hypothesis that there is no difference in the overall financial performance between the commercial banks, as well as the financial performances, model POLS would not change through the time; at the same time, the FEM model remove the non-observable, non-measurable, and permanent factors, but have an effect on the financial performance. In model REM, consider the non-observable, varied-through time, and affect the financial performance, they are random variables, no correlation with other explainable variables in the model REM. The results from models FEM1 and FEM2 have statistical meaning, the independent variables have statistical meaning at $1 \%, 5 \%$, and $10 \%$; except for model REM1, the bad debt ratio NPL, GDP has no statistical meaning.

Based on the test results, we chose between model OLS and FEM, OLS and REM, and REM and FEM. The VIF factors were less than 20 , therefore the model is not multicollinearity. The results from the F-test of model FEM1 showed a value of $p=0.0396<5 \%$, therefore the hypothesis $\mathrm{H} 0$ is rejected, choosing model FEM. However, there are some other reasons that made the FEM model an endogenous model. To resolve this problem, we used the different GMM - DGMM method. The final analysis' results are based on the linear regression using DGMM methods. Using Sargan test to test the exogenous variable, the results showed that p-value of model DGMM1 and DGMM2 were $0.99>5 \%$, concluding that the variables used in the DGMM model are exogenous variables.

\section{Discussion}

Based on the results about the influence of financial restructuring factors on financial performance, we have some discussion and suggestions as follow:

First, the financial performance factors of commercial banks have the regression function 0.311 (model DGMM1 dependent ROA), regression function 0.347 (model DGMM2 - dependent ROE) with the meaning of $1 \%$ showing the positive relationship with financial results. The results are consistent with the expectations and the research by Lee and Kim (2013).

Second, the debt ratio has a regression function - 0.00048 (model DGMM1) with 1\% meaning and 0.00181 (model DGMM2) with 5\% meaning. The result showed that the debt-to-total capital ratio has a negative relationship with financial performance, agreed with the expectations and research of Akhatar et al (2011), Osoro (2014). Due to the capital needs, many commercial banks have the capital structures using more debts by increasing deposits to loan. Commercial banks increasing capital with more debts leading to non-qualified loans, increase bad debt, increase credit risks, and decrease financial performance.
Third, capital ratio has the regression function of 0.130 (DGMM1 model) with 1\% meaning and 0.767 (DGMM2 model) with $1 \%$ meaning. The results showed that the capitalto-total asset ratio has a positive relationship with financial performance, thus, agreed with the authors' expectations and studies from others such as Dziobek and Pazarbasioglu (1997), Osoro (2014).

Fourth, the bad debt ratio has the regression function of -0.0189 (DGMM1 model) with 10\% meaning and -0.0397 (DGMM2 model) with 5\% meaning. Bad debt ratio has a negative relationship with financial performance, which agreed with the authors' expectations. Commercial banks performing financial restructuring focusing on bad debt can improve the financial performance. This result is also similar to the research by Rose (1994), Dziobek and Pazarbasioglu (1997), Kolapo et al (2012), Hsiao et al (2010).

Fifth, about the banks' size, both models had the same result showing a positive relationship between size and the financial performance, with the positive regression function for model GMM1 and GMM2: 0.00493 and 0.0516, with $1 \%$ meaning. This result is consistent with the studies by Hsiao et al (2010), Barako et al (2013), Kithinj (2017). The banks' size had the ability to attract more customers, increase revenue, and increase financial performance.

Sixth, economic growth rate has the regression function of 0.00289 (model DGMM1) and 0.0206 (model DGMM2), with $1 \%$ meaning, showing that in the regression period, commercial banks restructured because the customers were facing financial difficulties, not being able to pay their debts, bad debt increased and profit decreased. When the economy recovered, the customers were doing better, using more banks' services, and the financial performance of banks increased. The other authors such as Hsiao et al (2010), Akhar et al (2011) had a similar point of view on this issue.

Seventh, inflation rate has the regression function of -0.00165 (model DGMM1) and -0.0177 (model DGMM2), with $1 \%$ meaning, showing that increasing inflation rate leads to decrease in financial performance of the banks. This result also supports Akhar's research (2011)

Eighth, financial restructuring in the 1st and 2nd period have regression functions for model GMM1 and GMM2: $-0.00750,-0.00798$ và $-0.0772,-0.0906$, respectively. These regression functions showed that, the 1 st financial restructuring decreased the financial performance, the 2nd financial restructuring further decreased that financial performance. Restructuring requires the banking system to have a sustainable operation in the long run. The commercial banks with the requirement to increase the safety margin, decrease the mid-term loans, therefore profit decreased, and the research was done in a short time and could not show any increase in financial performance. However, research of Hsiao et al (2010) has a longer research time, and it did show an increase in the financial performance. 


\section{Conclusions}

This research investigates the influence of financial restructuring on the financial performance of Vietnam's commercial banks for the period 2008-2018. We divided the period into two sub-periods: before financial restructuring (2008-2011) and during financial restructuring (2012-2018), and we also divide the restructuring time into two periods - 2012-2015 and 2016-2018. The research is based on the secondary data from the audited financial reports of 28 commercial banks in Vietnam to form a data table (except for Bao Viet bank, which was established in 2009, therefore there is no information of this bank in 2008). We have used the quantitative research method to measure the influence of the variables representing the financial restructuring activities on the financial performance of Vietnam's commercial banks. The measurement methods used were: POLS, FEM, REM, GMM, and DGMM.

The results showed that account payables' restructure and capital's restructure are needed. Increasing owners' capital, decreasing payables would increase financial performances; bad debt restructure would decrease the bad debts; increase credit quality requirements would increase the financial performance. However, the restructuring for the period 2012-2015 and 2016-2018 did worsen the financial performance. One of the limitations of this research is that it does only cover the period before and during the restructuring time. The data need to be collected on a longer time period to evaluate the influence of restructuring on commercial banks after the restructuring period. Future research could add more data covering the period of three to five years after restructuring. Besides that, in this research, we did not make a difference between banks, therefore this could be another limitation that could be considered for further research.

\section{References}

Akhtar, M. F., Ali, K., \& Sadaqat, S. (2011). Factors influencing the profitability of Islamic banks of Pakistan. International Research Journal of Finance and Economics, 66(66), 1-8. Available at: http://joc.hcc.edu.pk/faculty_publications/ IRJFE_66_12.pdf

Arellano, M., \& Bond, O. (1995). Another look at the instrumental variable estimation of error-components models. Journal of Econometrics, 68, 29-51. https://doi.org/10.1016/03044076(94)01642-D

Barako, D. G., Ross, T., \& Brown, M. (2013). Firm specific factors and access to financial services. Unpublished Master's Thesis, University of New South Wales and Curtin University of Technology, UK.

Dao, B. T. T., \& Nguyen, K. A. (2020). Bank Capital Adequacy Ratio and Bank Performance in Vietnam: A Simultaneous
Equations Framework, Journal of Asian Finance, Economics and Business, 7(6), 39-46. https://doi.org/10.13106/jafeb.2020. vol7.no6.039

Denizer, C. A., Dinc, M., \& Tarimcillar, M. (2007). Financial liberalization and banking efficiency: Evidence from Turkey. Journal of Productivity Analysis, 27, 177-195. https://doi. org/10.1007/s11123-007-0035-9

Dziobek, H. C., \& Pazarbsioglu, C. (1997). Lessons from systemic bank restructuring: A survey of 24 countries. Working Paper No. 97/161. Washington, DC: International Monetary Fund. Retrieved July 20, 2020 from: https://www.imf.org/en/ Publications/WP/Issues/2016/12/30/Lessons-From-SystemicBank-Restructuring-A-Survey-of-24-Countries-2436

Gardner, M. J., Mills, D. L., \& Cooperman, E. S. (2004). Managing Financial Institutions. An Asset Liability Approach (4th ed.). New York, NY: The Dryden Press.

Harker, P. T. \& Zenios, S. A. (2000). What drives the performance of financial institutions? In: P.T. Harkerand \& S.A. Zenios (Eds.), Performance of Financial Institution - Efficiency, Innovation, and Regulation. Cambridge, UK: Cambridge University Press.

Hsiao, H. C., Chang, H., Cianci, A. M., \& Huang, L. H. (2010). First financial restructuring and operating efficiency: evidence from Taiwanese commercial banks. Journal of Banking \& Finance, 34(7), 1461-1471.

Hu, Y., \& Izumida, S. (2008). Ownership Concentration and Corporate Performance: A Causal Analysis with Japanese Panel Data. Corporate Governance: An International Review, 16(4), 342-358. https://doi.org/10.1111/j.1467-8683.2008.00690.x

Isik, I., \& Hassan, M. K. (2002). Technical, scale and allocative efficiencies of the Turkish banking industry. Journal of Banking and Finance, 26, 719-766. https://oi.org/10.1016/ S0378-4266(01)00167-4

Kithinji, A. M., Mwangi, M., Litondo, K., \& Ogutu, M. (2017). Bank Restructuring and Financial Performance. International Journal of Economics, Commerce and Management, 5(10), 84-98.

Kolapo, T. F., Ayeni, R. K., \& Oke, M. O. (2012). Credit risk and commercial banks'performance in nigeria: a panel model approach. Australian Journal of Business and Management Research, 2(2), 31-38.

Le, T. V., \& Buck, T. (2011). State ownership and listed firm performance: a universally negative governance relationship?. Journal of Management \& Governance, 15(2), 227-248 https:// doi.org/10.1007/s10997-009-9098-5

Lee, J. Y., \& Kim, D. (2013). Bank performance and its determinants in Korea. Japan and the World Economy, 27(2013), 83-94. https://doi.org/10.1016/j.japwor.2013.05.001

Majeed, M. K., Jun, K. C., Zia-Ur-Rehman, M., Mohsin, M., \& Rafiq, M. Z. (2020). The Board Size and Board Composition Impact on Financial Performance: An Evidence from the Pakistani and Chinese's Listed Banking Sector. Journal of Asian Finance, Economics and Business, 7(4), 81-95. https:// doi.org/10.13106/jafeb.2020.vol7.no4.81 
Osoro, P. M. (2014). The effect of financial restructuring on the financial performance of commercial banks in Kenya. Doctoral Dissertation, University of Nairobi, Kenya.

Rogovsky, N., Ozoux, P., Esser, D., Marple, T., \& Broughton, A. (2005). Restructuring for corporate success: A socially sensitive approach. Geneva, Switzerland: International Labour Organization.

Rose, P. S. (1994). The rescue of troubled banks; consequences for corporate strategies to deal with financial and operating stress. Journal of Financial and Strategic Decisions, 7(2), 1-17. Available at: http://www.financialdecisionsonline.org/archive/ pdffiles/v07n2/rose.pdf

Shih-Jen, K. H., \& McKay, R. B. (2002). Balanced scorecard: two perspectives. The CPA Journal, 72(3), 20-25.

Thompson, H. G. Jr., \& Garbacz, C. (2007). Mobile, fixed line and Internet service effects on global productive efficiency. Information Economics and Policy, 19(2), 189-214. https://doi.org/10.1016/j.infoecopol.2007.03.002

Thoraneenitiyan, N., \& Avkiran, N. K. (2009). Measuring the impact of restructuring and country-specific factors on the efficiency of post-crisis East Asian banking systems: Integrating DEA with SFA. Socio-Economic Planning Sciences, 43(4), 240-252. https://doi.org/10.1016/j.seps.2008.12.002

Tran, H. N., Tran, P. T., \& Nguyen, H. H. (2014). Impact of restructuring on the performance of Vietnamese commercial banks. Journal of Economic Development, 26(2), 26-47.

Tran, T. T. (2020). The Impact of Balanced Scorecard on Performance: The Case of Vietnamese Commercial Banks. Journal of Asian Finance, Economics and Business, 7(1), 71-79. https://doi.org/10.13106/jafeb.2020.vol7.no1.71

Worthington, A. C. (2009). Frontier efficiency measurement in deposit-taking financial mutual: a review of techniques, application, and future research directions. Discussion Papers Finance 2009(11). Griffith Business School, Griffith University, Australia. https://doi.org/10.1111/j.14678292.2009.00405.x

Zhao, T., Casu, B., \& Ferrari, A. (2010). The impact of regulatory reforms on cost structure, ownership and competition in Indian banking. Journal of Banking and Finance, 34(1), 246-254. https://doi.org/10.1016/j.jbankfin.2009.07.022 